University of California, Hastings College of the Law UC Hastings Scholarship Repository

Faculty Scholarship

1990

\title{
Socialist and Non-Socialist Approaches to Land Law: Continuity and Change in Somalia and Other African States
}

Ugo Mattei

UC Hastings College of the Law, matteiu@uchastings.edu

Follow this and additional works at: http://repository.uchastings.edu/faculty_scholarship

\section{Recommended Citation}

Ugo Mattei, Socialist and Non-Socialist Approaches to Land Law: Continuity and Change in Somalia and Other African States, 16 Rev. Socialist L. 17 (1990).

Available at: http://repository.uchastings.edu/faculty_scholarship/1286

This Article is brought to you for free and open access by UC Hastings Scholarship Repository. It has been accepted for inclusion in Faculty Scholarship by an authorized administrator of UC Hastings Scholarship Repository. For more information, please contact marcusc@uchastings.edu. 
SOCIALIST AND NON-SOCIALIST APPROACHES TO LAND LAW: CONTINUITY AND CHANGE IN SOMALIA AND OTHER AFRICAN STATES

\section{UGO MATTEI}

University of Trento

\section{Introduction}

This paper is an essay about how in modern Africa the structure of property rights is indifferent to ideological options.

Both in those countries which have followed a socialist way and in those which are trying to work out their development within a nonsocialist framework, the structure of property rights seems to remain the same. This article, mainly focused on land law, suggests that three land-use models are at play all around Africa. The socialist option has therefore not been able until now to offer any original solution comparable to those which it has provided in Eastern Europe or in Asia. Rather, the legal tools which are in use both in socialist and in nonsocialist African countries were already present in pre-independence days.

This is a case study which is particularly concerned with the Somali legal system. Somalia has, right after the Revolution of 1969 , closely followed a "scientific"' socialist option. Since the eighties nonetheless, official ideology has shown a major shift. These changes and their impact on the legal system seemed to me particularly useful in testing my assumption.

African land law is characterized by a high degree of complexity. This complexity is mainly due to a phenomenon of legal stratification. Stratification is the product of legal transplants and, broadly speaking, is by no means a peculiarity of African law. Nonetheless, it seems to me that 
African legal stratification may be considered to some extent unique. First because the different legal systems which play their role one after the other are very heterogeneous from the cultural, economic and political point of view and therefore scarcely mesh. Secondly because each system may still be alive even in those African contexts in which an attempt of imposing a single legal order has been made. These phenomena of heterogeneity and liveliness complicate any legal problem because of the deep divergencies of the solutions offered within each stratum. ${ }^{1}$

These basic complexities are sensibly augmented when the object of study is the law of property. Property law in fact on one hand reflects much more than other fields of the law all economic, political and cultural changes, as the allocation of goods is a key problem for any human organization. On the other hand, property is the domain of both the conscious and of the unconscious patterns of resistance against any change.

It is moreover very questionable to speak about "African property law". Within Africa there are so many radically different legal systems that to speak about them as a single entity would be of very dubious merit.

But even if we were to give up the task of a general description of African laws of property, the complexities we are talking about would not be much reduced. The description of Somali property law, in fact, is made difficult both by reasons related to the Somali legal system in general and by reasons related to land organization. ${ }^{2}$

From the first point of view, even on the African landscape, the State of Somalia has had a complex historical development and, therefore, has a complex legal system. In fact, even if the departure point was privileged in a minor ethnical division, in the subsequent stratification

1. An in depth discussion and a large bibliography on "stratification" is provided by M. Guadagni, Il diritto dei paesi Africani nella letteratura contemporanea, Trieste 1984, $27 \mathrm{ff}$.

2. For a general survey of the legal system of Somalia see R. Sacco, Le grandi linee del sistema giuridico somalo, Milan 1984. This work has been reviewed by A. Allott, 35 International and Comparative Law Quarterly 1986 and Rivista di Diritto Civile I $1987,305$. 
we find elements of all the major world legal systems. The substratum of customary law which the Somali people brought with them when conquering the country was first touched by the transplant of Islamic law. This very sophisticated body of rules enunciated by the Shafiitic school has played and still plays an active role particularly along the coasts of the country.

The two legal families which make up the western legal tradition, the civil law and the common law, have found their way to Somalia during the colonial experience. The common law has been imported to the North of the country, in the former British Somaliland. The civil law has been imposed on the South of the country by the Italian colonists. ${ }^{3}$

To avoid the false impression of a mixed legal system in Somalia, with the kind of problems that a comparative lawyer would find in such places as Louisiana, Quebec, Scotland or South Africa, it is important to retain the following ideas. The legal systems exported to Africa from Great Britain and Italy were the colonial ones and were similar to each other as regards the sources of the law. They were both statute (special statutes) based systems in order to overcome the difficulties in the knowledge of precedents and the lack of a developed legal literature. Moreover, the common law and the civil law had a different geographical scope and, at the moment of the unification of the northern and the southern part of the country, the latter somewhat prevailed over the former at least in the domain of private law: the independent Somali Civil Code is, for example, based on the Egyptian code and is therefore Napoleonic. ${ }^{4}$ Nonetheless some problems of cohabitation of the two western legal traditions, even if less dramatic than in the above mentioned countries, still remain.

To this already complex situation a new drastic change has occurred after the 1969 Revolution. A brand new socialist stratum has been im-

3. Compare R. Sacco, "Diffusion et dépérissement des modelès juridiques italiens en Afrique notamment en Somalie", in Dynamiques et Finalités des Droits Africains, (G. Conac, ed.), Paris 1980, 26 ff.

4. Compare O. Calliano, "Le code civil égyptien, véhicule pour la diffusion des modèles européens en Afrique", in Dynamiques, op.cit. note 3, $50 \mathrm{ff}$. 
posed on Somali law with the consequences that we will see in this paper. 5

If we take Professor David's classification of legal families ${ }^{6}$ we can in conclusion see that the Muslim family, the Romano-Germanic family, the common law family and the socialist family are present (beyond the traditional law) in a single legal system.

This seems enough to whet the appetite of every comparative lawyer interested in the interaction of legal models. Nonetheless it makes life difficult for anybody who attempts to answer a legal problem in a precise way, and particularly for any reformer who needs to have a clear map of the law (e.g., law of property) in order to adjust or change it in a realistic and workable way.

In the domain of the law of property, these general Somali legal complexities are amplified and made more dramatic because of the need for an efficient land use regulation as an integral step towards economic prosperity. As has been pointed out by a Somali scholar:

the major difficulties in front of whoever wants to examine Somali land law are due to the variety of the sources from which he must deduce the law. There are enacted and never enforced statutes, different and often contradictory practices, and it is by no means uncommon for there to be a conflict between State laws, Islamic law and Customary law. These difficulties, deriving from the coexistence of customary, Islamic and state law are one of the most fundamental problems that the new Democratic State has to solve. ${ }^{7}$

In order to make a first step in the direction of solving these problems, this paper will use a broad comparative and interdisciplinary approach. The first part of the paper will therefore be descriptive and will try to generalize some common patterns of African land law in order

5. For a general discussion of the impact of socialist law in muslim Africa see G. CrespiReghizzi, "L'influence des modèles juridiques socialistes en Afrique musulmane", in Dynamiques, op.cit. note 3, $34 \mathrm{ff}$.

6. R. David, Les Grands Systèmes de Droit Contemporaine, 7th ed., Paris 1978

7. M.H. Muddei, "La proprietà agricola in Somalia", Rivista di Diritto Agrario 1979, 296-298. 
to see whether these models are present in socialist Somalia and what is their role. The elaboration of simplified (but hopefully not simplistic) models seems to be the only way to deal with any phenomenon of complexity. A clear-cut representation of reality is required.

The second part of the paper will try to see whether the goal of wealth maximization can suggest something for a policy for land use in Somalia.

\section{The Group Centered Model}

A leading scholar, T. Olawale Elias, has solved the problem as to whether there is a model of African customary law generally applied in the continent. ${ }^{8}$ In his classical analysis, he points out that there are certainly many cultural differences between African populations but that these differences should not be over-emphasized. If over-emphasized, they will lead to a chaotic picture that does not correspond to the truth as it conceals all links with past connections. All the varieties of cultural (and therefore legal) customs are nothing more than variations of details around a few general themes.

As evidence of his observation Elias cites the fact that there are impressive analogies between customs of such different people as the Yanoubas, the Bantu, the Sudanese, the Ashantis and the Congolese. ${ }^{9}$

As we are not interested in details, particularly in the ones on the customary law of property which by its nature is impossible to be definitely stated, we can go ahead and describe the first model of African property: the customary one.

First of all, we should notice that the law related to land receives a treatment entirely different to that of all other kinds of property. This approach is shared within the western legal tradition by the common law while the Napoleonic model tends to state general rules related to any kind of property.

8. T.O. Elias, The Nature of African Customary Law, Manchester 1956; see also the same approach in Ideas and Procedures in African Customary Law, (M. Gluckman, ed.), Oxford 1969; A. Allott, Essays in African Law, London' 1960; N. Rouland, Anthropologie Juridique, Paris 1988, 252ff.

9. Elias, op.cit. note 8,3 . 
In the traditional model, land is considered as being in the ownership of the clan which deals with it according to the tradition rooted in its ancestors, in the interests of the present and future generations. The best description of this philosophy is the one offered by a Nigerian chief in front of the West African Lands Committee in 1912: "In my mind land belongs to a large family where some of its members are dead, a few are still alive and the majority are still to come". ${ }^{10}$

This conception gives land a state of inalienability, although this inalienability seems to be somewhat vaguely defined.

Let us try to see what is possible and what is impossible to do with the land according to African customary law. We may consider separately the three activities which give content to any property right: use of the land; defending it against usurpation by someone else; and selling it.

As regards individual use, we can first of all state that in the traditional model the individual is not considered as a single entity but as part of a group. In African traditional law today, as in the ancient law of the tribes (Germanic and of the Far East) studied by Henry Sumner Maine $^{11}$ there is no such distinction as the one, of Roman origin, between the law of property and the law of persons. Both are aspects of the same relationship between men and goods. ${ }^{12}$ This makes it somewhat futile and most of all difficult to look for individual powers. Moreover - and this caveat must be borne in mind throughout our description of the traditional model - the search for distinct individual rights is against the very nature of traditional law. Traditional law, in fact, "does not have the character of constancy and repetitiveness according to which a same set of facts must be governed by identical rules". ${ }^{13}$ Traditional law is unwritten. The very writing of it means to reduce it in repetitive schemes. Once so reduced it has lost its most salient feature: flexibility and adaptability, due to the fact that the rule of traditional law is the product of a great degree of discretion which

10. Quotation in Elias, op.cit. note 8, 162.

11. See H.S. Maine, Ancient Law, London 1861, repr. 1986, 202 ff.

12. The following discussion is based on Elias, op.cit. note 8, 162.

13. R. Sacco, "Diritti Stranieri e sistemi di diritto contemporanei", in Enciclopedia Giudicia, Rome 1989, 22. 
takes into account many aspects foreign to the controversy it must solve.

Usually land which belongs to the group is divided between subgroups and used by even smaller groups corresponding to different families. ${ }^{14}$ This means, in other words, that the individual (i.e., the chief of the family) enjoys possession of the land (in the English sense of the word) as opposed to the large group which has the ownership of it. On the piece of property allotted to him the individual can do whatever he wants in terms of enjoyment. But if he does not take advantage of it, another member of the group may obtain a new allocation of the individual piece of property. It is obviously to be taken into account that the use required in order to bar someone else's desire for that piece of property depends on the economic activity practised by the group. In the case of an activity such as grazing cattle, property may be enjoyed jointly by the members of the group without a subdivision of it.

As regards the possible ways of defending property, there is not much to be said. The group defends its property against other groups in the same way as it acquired the property: through warfare. Obviously there is not always the need of actual war. Sometimes the threat of it will be sufficient to discourage any interference. ${ }^{15}$

The individual can vindicate (obviously in a non-technical way) his own individual possession against another member of the group and can take action to ensure that his quiet enjoyment of the land is not interfered with. If the land is encroached by someone who is not a member of the group, the defence of the property becomes a matter to be dealt with by the collective by way of negotiation or war. If the wrongdoer is a member of the group, the Chief or the assembly should determine the dispute. The value of group cohesion counts for a lot in this decision-making process.

As regards the transfer of property, we may distinguish between the transfer inter vivos and the transfer mortis causa. The very idea of a

14. Compare G.B.A. Coker, Family Property among the Yanoubas, London 1966, 32.

15. Once again the analogy with the old Germanic tribal land use models is astonishing. Compare J. Gordley, Comparative Legal History (unpublished materials, Berkeley, 1988). See also, in general, H. Berman, Law and Revolution, Cambridge Ma. 1983. 
group which is not limited to the present generation suggests that this distinction makes sense only as regards individual powers.

The inalienability rule limits the group as represented by its Chief. The Chief is not a feudal lord. Even if during the colonial period some Chiefs transferred rights of exploitation to the Europeans pretending to be feudal lords, the economic and legal structure of property according to the model of customary law is not similar to the feudal structure.

The description of the kind of title vested in the individual allottee of a piece of land is one of the most fascinating as well as difficult problems in dealing with African land law:

a member's right to his holding . . . confers upon him powers of use and disposition scarcely distinguishable from those of an absolute freeholder under English law. His title is therefore, in a sense, that of a part owner of land belonging to his family. He is not a lessee; he is not a licensee, he is not, as is often said, an usufructuary. He pays tribute to nobody, is accountable to no one but himself, and his interest and powers far transcend those of the usufructuary under Roman law.

If this statement can be considered correct from the point of view of the power to use the land, from the point of view of disposition it seems a little too wide:

But a member's portion of family land cannot be sold by him or taken away from him in satisfaction of a debt, though he may pledge the use of his own portion for debt. He can in certain circumstances lease it and, with the consent of the owning group, sell or otherwise alienate his portion. ${ }^{16}$

As regards the powers of disposition after death, we may mention here

16. Elias, op.cit. note $8,165,166$. The description of the kind of property right held by the individual in Africa is a key problem for African law scholars and legal anthropologists. See e.g., A. Allott, "Towards a Definition of Absolute Ownership", Journal of African Law 1961, 99 ff; T.O. Elias, Nigerian Land Law, London 1971, 116; Rouland, op.cit. note 8. 
that succession can be considered as automatically in favor of his descendants. This means that the individual's holding does not come to an end at his death.

It is important to mention that this regime is not extended to immovable property other than land. This means that the individual can enjoy something like full ownership on all that he plants or builds on the land. If lawfully ejected by some other group member he may take away everything actually on the land. This makes it clear that the principle of accession is unknown to African customary law. The absence of this principle, together with the complete power of use of the land, is not without impact on the problem of land disposition:

in some cases his otherwise conditionally revocable title may become irrevocable in consequence of his having been allowed to build substantial houses or to grow permanent cash crops and other economic trees on his land: he is not to be lightly extruded from what is now his own family settlement. ${ }^{17}$

But this phenomenon has little to do with alienability which is only possible within strict limits and with the consent of the other family members.

It is very interesting to notice, at this point, that not all land is subjected to this regime. A fairly large part of it, particularly the wild bush, is not allotted to individuals but maintained in common for communal use. In this case, even if wild, the land is not without an owner. It is just unallocated land under the care of the Chief or of the Council of Elders:

a member of the community is, with the necessary consent, usually free to acquire a portion of it for himself by right of first cultivation as he is to enter upon any part of it for the purpose of hunting, wild game, tapping oil palm for palm wine, hiving bees and collecting their honey, or just grazing cattle or rearing poultry thereon. ${ }^{18}$

17. Elias, op.cit. note 8, 166.

18. Elias, op.cit. note 8,168 . This different pattern of land use based on maintaining 


\section{The Individual Centered Model}

The individual centered model can be also defined as the liberal ownership of land. This means that the individual can enjoy the land in the most absolute way provided that he does not unlawfully cause damage to his neighbours. When such an absolute right of ownership is recognized, the state shall not deprive the individual of it except in cases of public necessity and giving just compensation. Conventional examples of this model can be found in the French Code Civil and the American Constitution.

The basic economic idea which is pursued through this model of property is that individual self interest will lead the owner to the most efficient use of his land and, as a consequence, the common welfare will also be improved. ${ }^{19}$

This idea has found its way to Africa with non-African legal systems: first, with some aspects of Islamic law; then, and this is the most notable aspect, with European colonization. ${ }^{20}$ This section will try to demonstrate that large differences of style between common law and civil law have been lost in Africa: they have been overwhelmed by matters of colonial policy.

The French legal experience does not create particular problems: it is widely agreed that French law recognizes absolute ownership of land. It should be said, however, that, apart from the intrinsic contradiction

certain land periodically unoccupied has always struck western colonists as utterly inefficient. They could not recognize it as occupied land and therefore never respected property rights to it. This happened not only in Africa but also, for example, between the American colonists and the indigeneous American Indians. Compare Cronon, Changes in Land, Indians, Colonists and the Ecology of New England, New York 1983, 207 (see the large bibliography).

19. See e.g., H. Demsetz, "Towards a Theory of Property Rights", 57 American Economic Review 1967, 347, for a modern rationalization of this theory which dates back at least to Adam Smith and the Scottish School.

20. According to Professor R. Sacco, in "Conclusive Remarks" made to a symposium on African agrarian law held in Florence, March 1988, the model of individual ownership was never seriously experienced by European colonists in Africa. Nevertheless, it has been rejected by the new African States because Africans were aware of the criticism of this model in Europe. 
of article 544 of the French Civil Code ${ }^{21}$ the code does not contain any rules from the point of view of the remedies to defend the land. It may be enough, as an example, to mention that the Napoleonic code is not a satisfactory law as regards to the technical aspects to recover possession. Nonetheless, it is sufficient not to confuse the letter of the code with the whole of the French law of property to agree that the Roman absolute dominium is a concept very well known to all French based legal experiences.

There were basically three ways by which French absolute ownership was introduced in Africa. First, by direct importation from the very beginning of the colonial period - as in most parts of francophone Africa. The concept was not completely adopted however, as, apart from a few experiences, it was limited to the legal relationships between Europeans (and then not to all their transactions). ${ }^{22}$ Secondly, after Independence, the French model has not been totally rejected everywhere. Its intrinsic prestige became a vehicle of diffusion all around the former French colonies, exactly as it happened in Europe when the Napoleonic conquests reached their end after Waterloo (the Belgian example is very instructive from this point of view). This second kind of reception is not necessarily by re-enactment of the code or by new enactments. In some instances, as in the French Congo, the Courts (because of the legal convictions and education of the judges) simply continued to decide law of property cases as if the rules were still those of the French model. ${ }^{23}$ Finally, we may mention here the third way of reception: the one that may be called "indirect". This happens when a different (i.e., from a third country) but nevertheless French based code is adopted. The most famous example of this kind of reception can be found in the continentwide diffusion of the Egyptian code. ${ }^{24}$

21. Which on one hand speaks about the most absolute powers of the property right holder but, on the other hand, allows even administrative regulations to put limits on it. Compare, A. Gambaro, Ius aedificandi e nozione civilistica della proprietà, Milan 1976.

22. For all matters of property law in francophone Africa, see "Droit de biens", (Koussagan, ed.), in Encyclopédie Juridique de l'A frique, vol. V, 1982.

23. See field research results in M. Graziedei and U. Mattei, "Il Codigo Domaniale et Fondiario della Repubblica Popolare del Congo", 33 Rivista di Diritto Civile I $1987,77,106$.

24. See Calliano, op.cit. note 4. 
As is very well known, the French legal system after the (French) Revolution attempted a very drastic break with the past. In particular, in the domain of land law, the old feudal system, seen as the origin of every injustice, was completely abolished. The French experience, in this particular topic, has been followed by all the other civil law countries.

No such a break with the past happened in England. This historical accident is deeply relevant to one of the most notable divergencies between the common law and the civil law: the regime of land law.

The feudal model of property can be oversimplified in the following way. An original landlord transfers to another individual a legal entitlement to a particular piece of property keeping for himself certain prerogatives. The subsequently entitled person can transfer to a third person his title (or part of it) keeping for himself some prerogatives. The chain may continue. Each following entitlement may be differently shaped. The feudal model of land law thus developed in a most complex manner as each title is "real" and therefore must be recognized in perpetuity, in its particular form, by every subsequent market actor.

In the feudal model no entitlement can be absolute: not that of the original landlord as this must recognize all the subsequent titles, nor the subsequent entitlements, as they always have to respect some prerogatives. Seen from the point of view of the commodity object of the property right, the feudal model is characterized by many concurrent legal interests to it.

English property law has maintained such a structure. ${ }^{25}$ The basic idea is that all of the English land is the property of the Crown: all private entitlements to it are therefore not absolute. Nonetheless also under English law we can find an entitlement which is as absolute as any individual relationship with land may be: the so-called ownership in fee simple. Even if in theory the Queen is still the owner, the powers which may actually be exercised without the owner's consent are not smaller

25. For all matters of English property law a very convenient and instructive treatment is offered by Lawson and Rudden, An Introduction to the Law of Property, Oxford 1984. As to the problems arising from the introduction of the fee simple in West Africa, see A. Allott, New Essays in African Law, London 1970, 298. 
than under French law. Interesting evidence for this assumption may be found in an African case. In Tanganyika some land had been purchased under German law ${ }^{26}$ when the territory was under German administration. When the area came under British control, the Tanganyika Land Registry Ordinance came into force (1923). Section 5 of that ordinance only provided for the registration of "an estate in fee simple in land" or a leasehold. Was it possible to register, by its terms an absolute interest recognized under German law? The answer was yes.

If a native was previously entitled in Tanganyika to absolute ownership of any land, he remains so entitled under the British Statute notwithstanding that absolute ownership of the land by a private person is a concept strange to English law.

As we have already argued, this idea that there is no absolute ownership under English law is part of the folklore of the common law legal environment and must not be over emphasized if we do not want to reach an unrealistic picture. In any case, as Professor Anthony Allott said: "the English lawyer must lose his deep seated horror of absolute ownership of land when he goes to the colonies". 27

The ways by which English common law has found its way to Africa are too well known to give an account of them here. ${ }^{28} \mathrm{We}$ are more interested in showing that the model of absolute ownership in land was imported by the English in Africa and not just found (and recognized) there.

Let us take the case of Uganda. At the time when the British came to Uganda customary law reflected very much the group centered model that we have described in a previous paragraph. The idea of individual absolute ownership of land was totally unknown. ${ }^{29}$ The English colonists took into account the different economic conditions of the area where the powerful Buganda tribe lived as compared to those of the

26. The case is Attorney General v. Noti bin Ndugumbi (1954) 21 East African Cases Annotated, 43. See the discussion of this case as offered by Allott op.cit. note 8, 16.

27. Allott, op.cit. note 8, 17.

28. See Elias, "English Law and Africa", in Essays for Keeton, London 1967, 102; Allott, op.cit. note 8,3 ; id. " $L$ 'influence du droit anglais sur les systèmes juridiques africains" in Dynamiques, op.cit. note 3, 3; id. op.cit. note $25,9$.

29. The following discussion is based on D. Brown and A.P.J. Allen, An Introduction to the Law of Uganda, London 1968, 74. 
other areas of the country. In the Buganda area, from 1900 onwards, property rights were given to a number of landlords, mainly members of the royal family, Chiefs and other important people.

With the simultaneous introduction of monetary economy, land also became a source of profit through leasing and sale. Prior to 1900 these were unknown conceptions in Buganda land law. The system became known as mailo, from the English word mile . . . Originally there were about 4,000 mailo owners but, as plots were sold, resold and resold yet again, the plots became smaller and the number of mailo owners increased ... ${ }^{30}$

Outside the Buganda area the model of land law imported by the English was even more clearly absolute. The English protectorate "cherished the idea that much of the spare and unoccupied land could be settled by Europeans". Several such grants were made, such as to the Uganda Railway. But what kind of incentives were given from the legal point of view? "The few settlers who did come wanted an assurance that the land they occupied was theirs and that no one would take it away. The protectorate Government therefore gave them a freehold title". ${ }^{31}$ It seems to me that this is exactly the legal and economic essence of the individual centered model. The comparison with the Mailo system of Buganda shows how, apart from details, both proprietary systems introduced by the British in Uganda share the same philosophy: trusting a certain individual in order to obtain efficient land use. Policy reasons, therefore, overtook problems of legal style: civil law and common law used similar tools in the colonies.

\section{The State Centered Model}

The creation of a market of absolute property rights may lead to speculation. Individual absolute ownership when no controls are exercised

30. The 1900 Agreement was signed by the British Government and the Government of the Kabaka. See Brown and Allen, op.cit. note 29, 78.

31. Brown and Allen, op.cit. note $29,80$. 
may lead to opportunistic and anti-social behaviour in some groups of owners. A typical example is the accumulation by a few individuals of extensive tracts of land in order to re-sell them at a large profit after the efforts of the State have made them more valuable by creating railroads, roads or irrigation facilities. The above mentioned phenomenon may be controlled or reduced if the State takes an active role by assuming direct control of the land.

This section will show how at various degrees and with different ideological bases, this model has been followed both during the colonial experience and after independence, even in those African states which have chosen the socialist option. Let us briefly discuss this theoretical model of property organization.

The State is the owner of the property and deals with it both by way of direct use or by way of concession to individuals. When the use is direct it may be exercised by public agencies, corporations or cooperatives. ${ }^{32}$ In this case there is direct control of the land in order to obtain its best value. The economic results of this endeavour may be redistributed to individuals.

When the use is indirect, the State maintains eminent domain of the land and transfers limited conditional titles over it. Obviously both the length and/or the conditions of the title may vary greatly. Usually the length is sufficient to encourage private investment in the land.

In certain cases, as in the People's Republic of Congo, ${ }^{33}$ when the title expires it may be renewed or compensation may be granted for the Mise en valeur.

As regards the conditions to hold the title, they are usually linked to living on or working the land in such a manner as to improve its condition.

As we briefly mentioned before, this model of dealing with land is

32. The direct ownership of the State, a typically socialist pattern of property law, is seldom used in non-African Socialist countries as regards land ownership. It is much more common as regards means of production other than land. See G. Ajani, La proprietà delle formazioni sociali nel diritto dei paesi socialisti, Milan 1988. However, arts. 20 and 21 Fundamentals of Civil Legislation of the USSR, $1961 \mathrm{en-}$ title the State to direct ownership.

33. Art.86, L. 52/83. Compare Graziadei and Mattei, op.cit. note 23, 92. 
shared by African legal systems before and after independence. We obviously do not want to say that there have been no changes in land use in the process of African independence. We simply mean that the legal tools and techniques which were already in use in colonial days are also used in modern Africa. ${ }^{34}$ The goals may change as frequently and suddenly as political or ideological programs; but legal tools are the outcome of long and incremental scholarly and practical efforts and are a very scarce resource. This is the reason why the fundamental legal framework (at least in the domain of private law) resists revolutionary processes in Africa as well as everywhere else. ${ }^{35}$ As a matter of legal style, it is nonetheless important to note that a significant divergence occurs in the legal way by which African legal systems with civil or common law traditions reach the same results. Within the common law model, as what I have said in the previous paragraph should suggest, the structure of the law of property is easily adaptable in order to frame the land use model under discussion. It is sufficient for the State to transfer (exactly as did the feudal landlords) a leasehold title instead of a freehold one and to make use of the prerogatives of the landlord. ${ }^{36}$ For example, in Uganda to avoid urban property speculation by Asian traders the Protectorate Government granted them leasehold titles of limited length. ${ }^{37}$

More serious problems arose under the French conception of property. The political program pursued by the French colonizers immediately after their arrival in Africa was to eradicate African people from their group organization in order to deal with them as individuals using an approach considered more efficient. The traditional group centered model of land use organization was a deep obstacle to this policy. They therefore actively sought to create a market of individual property rights through the introduction of the Napoleonic code and of the

34. See infra as regards the Somali experience.

35. See R. Sacco, "The Romanist Substratum in the Civil Law of the Socialist Countries", 14 Rev.Soc.Law 1988 No.1, 65-86.

36. As to the differences between freehold and leasehold after the Law of Property Act, (1925), see Lawson and Rudden, op.cit. note 25.

37. See Brown and Allen, op.cit. note $29,80$. 
Thorens system. ${ }^{38}$ After the First World War it was clear that this policy had failed in the countryside where traditional resistance was too strong. On the other hand, it was also overwhelmed (particularly in the richer areas) by speculation not only by the Europeans, but also - and that was seen as really intolerable - by some African people who claimed to apply literally the formal equality between individuals typical of the Napoleonic code. A need for a State centered land use policy was felt: legal tools were required. An attempt was made to do in Africa what would not have been possible in the home country.

French folklore required that the actual structure of the law of property should not be altered in any way but that the operation of public law should remove some of the sources of private appropriation. These commodities were to be considered Domain d'état.

Following an initial experience in Algeria, a new public law organization of property has been widely introduced in francophone Africa. All commodities of particular economic importance (primarily land) are considered the property of the State and classified in two separate categories with different legal regimes in terms of use and alienability, i.e., the domain publique and the domain privé. ${ }^{39}$

When independence arrived, a large number of former French (and Belgian) colonies such as Senegal, Cameroun, Zaire, Togo and the Congo, ${ }^{40}$ undertook the program of substituting the colonial legislation by new statutes with the goal of a public welfare land use regulation. ${ }^{41}$

38. See supra note 21 . The statute which provided the basis of the so-called immatriculation régime is the Decrét 28/3/1989 relatif ou régime de la propriété foncière au Congo Français, in Bulletin Officiel des Colonies, 1899, 346. See Le Roy, "Les Objectifs de la Colonization française ou belge", in Koussagan, op.cit. note 22, 85 .

39. See De Laubadere, Traité de droit administratif, vol.II, Paris 1975, 120; F. AubyDucos Ader, Droit Administratif, Paris 1979, 237.

40. Senegal: Loi 64-46, 7/6/1964, Code du domain de l'Etat, Journal Officiel République Sénégal 11/7/1964, 906. See: Debene, "Regards sur le droit foncier sénégalais: un seul droit pour deux rêves", Revue International de droit comparé (hereinafter cited as Rev.Int.Comp.) 1986, I, 76; Caveriviere, "Incertitudes et devenir du droit foncier sénégalais", Rev.Int. Comp. 1986, I, 99. This may be considered the leading work. Cameroun: Ordonnance 6/7/1974 and Décret 27/4/1976 in Journal Officiel (hereinafter cited as J.O.) 1/5/1976, 13; Togo: Ordonnance $\mathbf{n}$. 12, 6/3/1974, J.O. 1974, 113; Zaire: Loi n. 73.021, 20/7/1973, J.O. 1/2/1974, 113 ; Congo: Loi 52-1983, Code Domanial et Foncier for a detailed discussion see Encyclopédie Juridique, op.cit. note 22.

41. See Breton, "Le domaine de l'Etat", in Encyclopédie Juridique, op.cit. note 22. 
Without discarding the tools of the past, the new states have organized themselves using two models. The main difference between them depends on a basic political and economic option: whether land can be the object of private property or not. In the first case, of which Senegal is the foremost example (1964), the need for an extension of public property is nonetheless considered important. The institutions of $d o-$ main publique and domain privé are maintained. Close to these concepts, the newborn domain national gives the State certain powers of administration in the interest of the nation. If the socialist option does not allow private ownership of land, the State will be the owner of all of the land - the legal tools are the same as in the colonial period: the domain publique and the domain privé. ${ }^{42}$

The experience in francophone Africa should be sufficient evidence of our opening assumption that both colonial and post independence (even socialist) models of land use can be classified within the same State centered model.

Needless to say, we can also find functionally similar land use regulations in modern anglophone legal systems. These impressive analogies which transcend legal families and styles encourage certain scholars to speak about a present unique legal experience: the law of development. ${ }^{43}$ We may add that the tendency towards adapting legal institutions to the particular social and economic problems that they have to solve is a typical feature of the State centered model. In the domain of the law of property this attitude leads the large majority of African legal systems to enact different rules for urban and rural property respectively. ${ }^{44}$

42. See Sacco, op.cit. note 20; the reasons for keeping pre-independence tools are analyzed by Owona, Un droit administratif de transition vers le socialisme: l'exemple de la R.P.C., Penant 1978, 165.

43. See the discussion in Guadagni, op.cit. note 1, 52 .

44. See e.g., Tribillon, "Présentation de quelques instruments de droit urbain africain francophone: concession, permis d'habiter, permis d'occuper", in Centre d'Etudes de Gestion Economique du Territoire. La croissance périphérique des villes du tiers monde, Bordeaux 1980, 465; see also many of the contributions to the collective volume Enjeux fanciers en Afrique Noire, Paris 1983. 


\section{The Relationship Between Land Use Models}

It seems to me that a basic economic idea is shared by the individual centered and by the concessionary model which we have discussed: the creation of incentives for individual entrepreneurship. The difference between the two models is therefore legal as the latter introduces a legal check on the individual's activity on the land which is unknown to the former. On the other hand, neither the economic substance nor the legal form of these models is shared by the group centered model of traditional law. The idea of the individual entrepreneurship and of its potential productive outcome was simply unknown to traditional law. An interesting question could be the position of the socialist cooperative in this framework. This institution is particularly cherished by those African regimes (including Somalia) which have followed the socialist option. It seems to me that the cooperative model can be considered in two ways. On the one hand it is typically group-centered. But on the other hand, if the results of its activities are intended for the market it may be considered individual centered. The presence of such a mixed structured model is not a surprise for us.

As we have already said at the beginning, the coexistence of different legal systems and structures is a peculiarity of African law. This is true also in the domain of the law of property, and it is true also in Somalia. The models of land law that we have discussed do not exist anywhere in a pure form. They usually coexist: land law can therefore be considered - despite political or ideological proclamations - to be a mixed model everywhere. The ingredients of the mixtures are the same everywhere but as in every recipe, they vary greatly in quantity. ${ }^{45}$

The coexistence of different land use models may vary following two patterns: a) different lands may be subject to different models of property as, for example, during the colonial period, urban and rural areas and $b$ ) the same land may be the object of different models because of a phenomenon of stratification and resistance. This second way of interaction of the different models of land law is one that at the same time

45. See Sacco, op.cit. note 20. 
is interesting and peculiar to African law. In this case we can see a phenomenon of competition between models. ${ }^{46}$

A typical African pattern of competition is that between the traditional group centered model and the colonial individual centered model in the countryside. An interesting example of this may once again be taken from francophone Africa ${ }^{47}$ There the attempts to create a market of private property in the countryside by means of the Torrens System or the mechanism of individual concession of lands considered as vacantes et sans maitre, received a clear defeat by the traditional model of property: the power which has been allowed to the indigenous population to register the land in their actual possession or to obtain a free concession by the State has never been used. It was soon clear that the reason why the indigenous people refused to make use of this power was not just technical; instead "they were convinced to be enjoying, by family tradition, a title that, although collective, was immeasurably better than the one that was offered to them". 48

After this first failure, an attempt was made to introduce procedures to ascertain traditional rights; but the colonizers also lost the second round because an individual introduction of the procedure was required which was obviously an obstacle to the recognition of customary rights because of their collective nature. ${ }^{49}$

A truly innovative step towards the solution of these problems has been taken by those African systems which, following the socialist option, have encouraged the creation of cooperatives. An attempt was made by these means to adopt a modern legal form which is compatible with the traditional economic and cultural substance.

46. See U. Mattei and F. Pulitini, "A Competitive Model of Legal Rules", in Competitive Politics, papers of the third Colombella Seminar held in Dourdan, France in September 1988.

47. Compare Alliott, "Les Résistances traditionelles au droit moderne dans les états d'Afrique francophone et au Madagascar', in Alliott, Etudes de Droit Africain et Malgache, Paris 1965.

48. Dareste, Le régime de la propriété foncière en Afrique Occidental Française, 1906, 16.

49. See Décret du 10/2/1938 instituant un mode de constatation des droits fonciers indigènes in Journal Officiel Afrique Equatoriale Française 31, (1938). Compare Demaison, "Le Régime de la propriété foncière en Afrique Equatoriale Française", R.J.P.U.F. 1956, 426. 


\section{Models in Socialist Somalia}

At this point it is interesting to turn to the Somalian version of land law. ${ }^{50}$ After a brief description of the main lines of its land use law, we shall try to see whether their relationship can be better described within the pattern of model a) or model b) which are described in the previous paragraph 5. In the second case we shall try to see what is the result of the process of competition and if it is possible to learn something from its prescriptive terms.

An initial impression that a scholar will receive in approaching the law of property in Somalia is that it is very incomplete. Despite the effort in law-making of the present regime, characterized by the enactment of a Civil Code and of two special statutes devoted to property, many areas of land law are not yet covered by an adequate legal framework. The Constitution of 1979 provides a framework for land law which is coherent with a socialist option. ${ }^{51}$ The constitutional rules relevant to property can be found in the first title of the third part of the supreme law of the land, which is devoted to the economic organization.

The following basic principles are set out there: the land, together with its natural resources and those of the sea, is the property of the State. The economic organization will be planned but "a mixed economy consisting in a common property of the State and of certain other subjects of rights is not discouraged". The cooperative organization is encouraged as the owner of property as being considered a possible intermediate economic organization between the individual and the State. ${ }^{52}$

Around these provisions which (as usual at the Constitutional level inside and outside Africa) do not have a technical content, a certain number of special statutes concerning waters and mines clearly display a socialist content.

50. The following discussion is based on M. Guadagni, Xeerka Beraha, Diritto fondiario somalo, Milan 1981; Sacco, op.cit. note 2, 171; Muddei, op.cit. note 7.

51. See G. Ajani, "The 1979 Socialist Constitution. The Socialist and African Patterns and the European Style", 8 Rev.Soc.Law 1982 No.3, 259-270.

52. Compare Sacco, op.cit. note 3,181 
Immediately after the Revolution, the Law on Social Protection started the campaign against tribalism by assigning to the State all collective rights on land and on immovable property and adopted a system of concessions by the State as a model of land use regulation. ${ }^{53}$ This approach has been followed by the two important statutes on urban land use (1973) and on agrarian property (1975)..$^{54}$

The sources of land law are completed by the Civil Code of 1973. Within this code seven articles are devoted, following a typically civil law approach, to the goods which are the object of property rights. A huge number of articles (252) are generally devoted to the right of property and to the other limited property rights typical of the Romanistic approach.

All the sources that we have mentioned have been enacted by the socialist regime. However, if we compare them with the typical structure of socialist property we will not find, in technical terms, much of it: from the political point of view, as Professor R. Sacco points out (apart from the Civil Code, which deserves a separate mention) they are socialist elements of the Somali legal system; but from the point of view of technical legal form, they do not provide the characteristic pattern of European socialist law: socialist ownership of the State with its related power of operative management by the socialist enterprise. ${ }^{55}$ It may therefore be of interest to develop a closer insight into the relations between Somali law and the typical features of socialist East European law. This analysis will be provided in a following section of this paper.

On the other hand, one may note the coherence between the rules enacted in 1973 and 1975 (and more recently the ones of urbanism of 1980) with the State centered concessionary model obtained by considering other African experiences. The ownership of the land belongs

53. Guadagni, op.cit. note 50, 233 points out that the Law of Social Protection though fully coherent with the socialist option, enacts provisions which have already been drafted during the so-called parliamentary period (i.e., after Independence but before the Revolution).

54. These statutes are briefly discussed in detail by Sacco, op.cit. note 2, 177. They may be conveniently found in appendice to Guadagni, op.cit. note 50 and discussed in depth, 290.

55. R. Sacco, paper delivered at the third Congress of Somali Studies. 
to the State in both urban and rural areas. As in other African experiences, ${ }^{56}$ the need to guarantee investments and to protect vested rights may lead to the presence of some apparently contradictory legal provisions: article 9 of the 1973 statute which grants compensation for the appropriation of immovable property is from this point of view very instructive. The way of overcoming these kinds of difficulties is to reach a formalized theory of eminent domain. ${ }^{57}$

The individual title to land obtained by concession from the State, varies depending on whether the land is located in the town or in the countryside. It also differs as to whether the person entitled is a physical person or a cooperative. In the case of urban land the rules are contained in chapter three of the statute of 1973 . The titles are granted by the Ministry of Public Enterprises. They are perpetual titles purchased for money. The person entitled must make use of the land in a way which is consistent with the rules contained in the concession. In the event of violations the concession may be revoked. Buildings are in the ownership of the person entitled, but no speculative use of the concession (which is personal) is admitted.

In the case of rural land, the concession is temporary ( 50 years) if the person entitled is a physical person. It is perpetual in all other cases, mainly those of cooperatives, which are greatly encouraged by the State since 1973.

These rules, though in a certain respect detailed as regards the procedures of concession; do not offer a qualification to the individual legal title to the land. The most serious consequence of this lacuna faces the person entitled when he is unlawfully disturbed in his enjoyment of the land. Can he act directly against the alleged wrongdoer or must he plea for the intervention of the State in order to maintain the quiet enjoyment of his property? ${ }^{58}$ In other words, what is the role of the individual centered model in Somalia?

The answer to this question seems to me deeply linked to the position

56. See for example, the problems arising in the People's Republic of Congo as regards the relationship between the droit de superfice of the individual and the ownership of the State. See also Graziadei and Mattei, op.cit. note 23, 96.

57. See Sacco, op.cit. note $2,178$.

58. See Sacco, op.cit. note 2, 179. 
that Islamic law enjoys in the Somali legal system. A widely shared opinion amongst African law scholars maintains a distinction between the African legal systems depending on the presence or absence of Islam. In the domain of the law of property, nonetheless, the Shariica does not play a very important role in Africa. The reason for this is that in order to penetrate the continent, Islamic law has to a certain extent respected the system of land use regulation that it found. ${ }^{59}$ Nonetheless, the model of Islamic property can be considered individual centered: meaning that the entitled person (either a physical person or a corporative body) enjoys a property right theoretically free from external limits. The entitlement is therefore transferable both inter vivos and mortis causa.$^{60}$ In Somalia this Islamic individual centered model of property law arrived with the Islamic immigrants and its range of influence.is mainly limited to the coast and to a very small number of properties inland. ${ }^{61}$ The relationship between Somali traditional law and Islamic property law has not always been friendly. Typical from this point of view is the property of the Jamiica, a sort of Islamic congregation. The Jamiica, following various procedures, became a landowner. The land ceded to the Jamiica by the tribal group had a very ambiguous legal status: according to the xeer (traditional law) the Jamiica held a temporary title subject only to the power of eminent domain of the tribal group. According to Islamic law, on the other hand, it was a waqf which enjoys an absolute title. ${ }^{62}$

It is important to notice that with the growth of the modern State, Islam has been encouraged in Somalia by being recognized as the official religion. In the domain of the law of property, Islamic property rights are individual centered and therefore tend to be consistent with the program of the eradication of tribalism: moreover, by very old Islamic tradition, within the town individual enjoyment of land requires the permission of the public authority and always has the character of

59. For a study on the penetration of Islamic law in Africa, see J.N.D. Anderson, Islamic Law in Africa, 2nd. ed., London 1978.

60. Compare D. Santillana, Istituzioni di diritto musulmano malachita con riguardo anche al sistema sciafiita, vol. 1, Rome 1926, 294.

61. Compare Sacco, op.cit. note 2, 32.

62. See Sacco, op.cit. note 2, 172. 
a temporary concession. ${ }^{63}$ Within Islamic law there are therefore both what we have called the individual centered and the State centered models of property: there is no doubt that they are appreciated by the modern State authorities.

Apart from Islamic law (which is still in force as an official source of the law) the individual centered model of property law is in force in Somalia within the Civil Code of 1973 which is, as already mentioned, an adaptation of the Egyptian code. This latter code is based on French law. Its role has until now been very limited in the domain of land law despite the high number of articles it devotes to the law of property. This may appear strange if we consider that after the State centered ideology which immediately followed the Revolution, the economic policy of the Government is shifting towards an encouragement of individual enterprise and therefore, towards the guarantee of individual property rights. ${ }^{64}$

As Professor Sacco points out "in this evolution of land law the Civil Code did not play any role . . . it ignores the concessions, the public property and the allocation of commodities to the State enterprise". To this we can add that it also ignores the co-ownership of buildings and, what is even worse, all actions in defence of property rights. ${ }^{65}$ Nonetheless, it is sufficient not to confuse the text of enacted statutes with the law and to consider that in dealing with the defence of property the Somali judge will apply the rules that he learnt when he was a student. The scholarly tradition in Somalia, mainly based on the Italian legal experience is, from this point of view, a very important vehicle of diffusion of the individual centered model. ${ }^{66}$

As we have already seen, the African process of independence has not broken with the past. This is demonstrated by the enactment of the Civil Code as well as by the other statutes on property law which have reenacted a regime structurally similar to the colonial one. We may see

63. See Santillana, op.cit. note 60, 268.

64. See e.g., Somalia: Agriculture in the Wind of Change, (P. Conze and T. Labahn, eds.), Saarbrücken-Schafbrücke 1986; Sacco, op.cit. note 2, 177.

65. See Sacco, op.cit. note 2, 177.

66. See Bootan, Deghey and Farah, "Somalia" in Legal Scholarship in Africa, (M. Guadagni, ed.), Trento 1989, 129. 
moreover that Somalia has not broken with the Italian scholarly tradition. This link is important as many rules particularly useful for the task of efficient land use development may be found in the Italian experience. There is a need of legal solutions in order to implement the economic policy of development. Interesting models may be found anywhere.

Italian law, first of all, provides for a variety of legal remedies to defend land. These techniques which can be found within the Code and within case law or doctrinal developments provide a large range of both property and liability rules. ${ }^{67}$ All these remedial options combined together offer the judge the possibility of dealing with these disputes between conflicting property rights in an equitable and efficient way. Furthermore, it is well known that Italian private law provides for the qualification and administration of an entitlement which is very similar to that enjoyed by the holder of a concession obtained according to the Somali statutes of 1973 and $1975 .^{68}$ Articles $957-977$ of the Italian Civil Code in fact describe an entitlement which is considered as a property right but which obliges the entitled person to improve the condition of the land.

If the land is not improved the individual holding the power of eminent domain may exercise it, putting an end to the relationship. The entitlement can be for a term of years (not shorter than twenty) or for ever. At the end of the relationship all improvements which cannot be withdrawn from the land are fully compensated by the holder of the eminent domain power (art .975). This last characteristic of the entitlement is important so as not to discourage investment. From the point of view of remedies, being the essence of every property right, there is no difference between the powers of the entitlement under discussion and absolute ownership. The holder of the eminent domain power does not play any role from this point of view. His role is limited to receiving the fees and to check on the improvements. ${ }^{69}$

67. See U. Mattei, Tutela inhibitoria e tutela risarcitoria, Milan 1987.

68. See Sacco, op.cit. note 2, 180.

69. An English translation of the Italian Civil Code is conveniently provided by J.H. Merryman in M. Beltrano and G.E. Longo, The Italian Civil Code, New York 1969. 
At this point it seems clear to me that if what we have said makes some sense, there is sufficient ground in Somali law to say that the State is the holder of a power of eminent domain which entitles it to receive the fees for the concession and to check the improvements of the land. Within this theory of eminent domain, the holder of the concession seems to maintain the power of defending his property right in Court. Problems do arise, however, in this construction from the point of view of jurisdiction: whether it should be maintained in the special courts where political matters involving the State are dealt with or whether it should be shifted to the ordinary courts. We will deal with this problem in the final part of the paper.

A few words are needed about the role of the group centered model in Somalia. We do not want to go into the details of it but simply to see what is its position in present day Somali legal organization. Xeerha Beeraha, the Somali way of speaking about traditional land use, is strictly connected with the nomad organization peculiar to most of the country. ${ }^{70}$ Its practical functioning is similar to the description we have given in a previous paragraph. The large group is the owner. Within it, possession is divided between smaller groups and occasionally between single families. It can be enjoyed in common where there is no need of a stable relationship between the individual and the land. This strong link with the nomad organization is in a certain sense the most notable limit of the possibility of developing traditional law according to the changing needs of the society. On the other hand, it is its greatest point of strength in comparison with the other models of property. From the first point of view, in certain conditions, as has already happened settlement may become a matter of survival. It is hard to believe that the group centered model is very promising in the search for a rational agricultural exploitation of the land. ${ }^{71}$ From the second point of view, nomadism which is strongly rooted as a way of life and a pattern of survival favors the traditional organization of land use. Such things as the

70. See Guadagni, op.cit. note 50.

71. See J. Janzen, "The Process of Nomadic Sedentarization - Distinguishing Features, Problems and Consequences for Somali Development Policy", in Somalia: Agriculture, op.cit. note 64, 73, 77. 
power of a customary Chief, the inalienability of land belonging to the family, the communal enjoyment of land and, most of all, the very flexible (and therefore equitable) organization of the limits of property rights are not easily replaced by a piece of legislation. Any enacted statute, however prestigious and strongly supported by the authorities (as is the case with the Law of Social Protection which is aimed at abolishing customary rights of land use) will remain without any effect if it does not take into account cultural factors which exist everywhere, but most notably in Africa, where there is a large gap between the enacted law ("the law in the books") and the shared customs of the people ("the law in action"). If the patterns of resistance are justified by an effective economic reason it may happen that the law in the books ends up following the law in action as the result of the evolutionary process which shapes the law. This is exactly what happened in Somalia: the Law of Social Protection has failed, as regards the part relating to land law, to replace the customary law which remains the law in action from the point of view of both land ownership and management. It is very important to note that a statute of $1979^{72}$ now regulates grazing without explicitly enacting the regime of concessions (i.e., the State centered model) which is prescribed by the Law of Social Protection and by subsequent statutes. This means that a very important aspect of Somali economic organization is now governed by legal tools of traditional origin, the same tools against which the regime originally concentrated its battle for reforms.

This short description can be summarized in the following way. At the level of the law in the books, it is possible to describe Somali land law within the framework previously considered - different properties are subject to different legal regimes according to their nature. The only serious problem which is faced by this rational framework for land law is the role of the Civil Code which seems a somewhat foreign body in the context of the pursued State centered model of land use. Its presence, nonetheless, may have an important meaning as a promise to

72. See Sh 4/2/1979, n. 3 in F.R.L. 1, R. 2, 25/2/1979. The problem of the interaction between customary law and modern law is the subject of research by Muddei, op.cit. note 50 . 
implement the legal framework for a mixed economy in future (see Art. 41 of the Constitution).

At this point, it must be said that the prevailing State centered model has a consequence which must be underlined here: in practically all litigation related to land law the State may be a party. Its presence changes the jurisdiction of the Court for the Security of the State, into one of a typical political court of revolutionary origins which is not subject to the ordinary review of the Supreme Court but merely to the power of annulment by the President. In the domain of the law of property the consequences of this jurisdiction are summarized by a leading scholar in the following way:

through this mechanism the law of property of the Civil Code inspired by ideas of freedom and guarantees leaves the high ground to a law of property which is sensitive to every political and ideological issue typical of an African developing country and it is therefore subject to controls and powers which are felt to pursue those issues. $^{73}$

If we leave the law in the books, it seems to me that the only realistic way of describing this kind of land use organization is to adopt the second framework previously outlined. The different models of land use are simultaneously present and competing all over the country. There are patterns of resistance to change due not only to the xeer in the countryside, but also to the strong gravitational force of a Civil Code for a judge who has received his legal education on a civil legal system. ${ }^{74}$ To this we can add that certain judges do know Islamic law and that a large variety of legal issues will never reach the courts but will be decided more or less formally by various individuals (customary Chiefs, local political leaders and so on). As a result of this competition, five radically different inputs have produced in Somalia in the domain of the law

73. Sacco, op.cit. note 55 .

74. The widespread role still played by Italian legal culture in Somalia can be perceived by the fact that legal education is still in Italian. See Bootan, Deghey and Farah, op.cit. note 66 . 
of property, the three models of land use which we have seen are common to the whole of African law.

This pattern, which cuts through ideological and political traditions, consists throughout Africa in a reshaping of legal models coming from abroad, the civil and common law competing with the traditional law and (where present) with the Shariica. The result seems to be a common core of African law which "probably will be in the future, the African contribution to a world wide common law". ${ }^{75}$

\section{African Law and Socialist Law: a Further Insight}

The socialist option in Africa has followed a large variety of patterns. The theory of an unique way to communism which characterizes the orthodox doctrines of scientific socialism has been challenged in various ways, the most characteristic of which seems to be known as humanitarian socialism, African socialism or, more simply, négritude. ${ }^{76}$

These approaches, widespread in such African countries as Tanzania, Algeria or Senegal, are characterized by the rejection of colonial exploitation and of the East European socialist model. In this view, scientific socialism is seen as unfitted to African conditions as it is hard to transplant to Africa such a thing as the idea of the struggle between social classes.

On the other hand, an affirmative common pattern of African socialism is the tendency towards a unitary centralized model as opposed to the decentralized tribal structure of society.

If we were right in our initial assumption that the law of property, more than any other field of law, might be used to test the reality of changes, we can see the first major difference between East European socialist property law and African socialist property law which may lead us to conclude that the 'African way' is really different. As is well

75. Sacco, op.cit. note 2, 282.

76. Compare Hazard, "Négritude, Socialism and the Law", 65 Columbia Law Review 1965, 778. See also La scelta socialista in Etiopa, Somalia e Tanzania, (M. Guadagni, ed.), Trieste 1979. 
known, according to the widespread socialist doctrine of property law, all goods are classified according to their destination, whether as a means of production or of consumption. To deal with the first category, the notion of socialist ownership has been created. Accordingly, private ownership of means of production tended to gradually disappear in practically all European socialist countries. ${ }^{77}$ To deal with the means of consumption, on the other hand, the idea of personal property has been created. ${ }^{78}$ This basic threefold classification of the socialist law of property is unknown anywhere in Africa. For example, in Somalia as in Madagascar and other African countries ${ }^{79}$ there is no State ownership over industrial as well as agricultural means of production. Means of production, where nationalized, are in the full ownership of the State enterprise created in order to use them. ${ }^{80}$ This seems to be the reason why Professor Viktor Knapp in his masterly description of socialist property has dealt with Asian countries but omitted Africa.

Land law is heterogeneous in both European and African contexts. In both continents we can basically find two patterns; the first approach, which considers land necessarily as a means of production, results in the complete nationalization of the land. Individuals may use it only as concessionaries. This is the Soviet model ${ }^{81}$ which has been followed in Asia by Mongolia and in Africa, among others, by the People's Republic of Congo and Somalia. A different approach followed, for example, in Europe by Czechoslovakia and in Africa by Senegal, does not necessarily consider land as a means of production and,

77. Compare V. Knapp, "Structural Variations in Property Law, Socialist Countries", International Encyclopedia of Comparative Law, Tübingen/The Hague 1974, 44; W. Brus, Socialist Ownership and Political Systems, London 1975, 27.

78. Compare K. Malfliet, "The Economic Function and Purpose of Soviet Personal Property and its Legal Implications", 11 Rev.Soc.Law 1986 No.1, 203. Scholars have shown how state property enjoys a far superior status in the described classification of property rights. See Zile, "The Taking and Precariousness of NonState Property in Soviet Law", 12 Rev.Soc.Law No.3, 1986, 203.

79. Compare Sacco, op.cit. note 2, 190 and Ramarolanto and Ratia, "L'enterprise socialiste à Madagascar", Rev.Int.Comp. 1984, 541.

80. This difference between African socialism and East European socialism is also stressed in Sacco, op.cit. note 2, 190 note 39.

81. Compare K. Stoyanovitch, Le régime de la propriété en U.R.S.S., Paris 1962, 117 $f f$. 
therefore, allows it to be private property. This theoretical difference, however, may largely be obliterated if attention is focused on the powers of the individual. In both contexts they may in fact coincide.

Both African and European socialist countries are fascinated by the idea of a planned economy. However, in Europe things have been carried much further. Plans are in fact binding on every economic actor, while in Africa they are not binding either in theory or practice. ${ }^{82}$

The attitude of Somalia towards socialism after the 1969 Revolution (which brought President Siad to power) has been pretty clear: orthodox marxism-leninism. The good relationship between Siad and the Soviet Union induced Somalia to abandon the humanitarian African socialist mould while following the Soviet model even in its more extreme tendency towards a centralized State controlled approach to the economy. The practical consequences of this ideological option has been on the one hand, the programs of forced settlement of nomads and on the other hand, the nationalization of all land.

As has been pointed out in a comment on the then brand new Somali Constitution of 1979 , despite these political proclamations, the realization of scientific socialism in Somalia was far away. ${ }^{83}$ There is no doubt that since the dramatic breakdown of the relationship between Mogadishu and Moscow which followed the Soviet choice of supporting Ethiopia in the Ogaden war, the realization of scientific socialism is even further away. ${ }^{84}$ Nonetheless, right now the change of mentality towards the State controlled economy has not had any results affecting the legal system which maintains a notable variety of socialist patterns. But, as we have seen, these patterns are neither exclusive nor of a specifically Soviet character. A few examples will be sufficient to understand this phenomenon that seems to link, from a law-in-action point of view, Somalia to African socialist legal systems much more than it would seem by just reading the Party Program.

At the level of general classifications of property law, as we have

82. Compare Ajani, "The Somali Constitution: the Socialist and African Patterns and the European Style", 8 Rev.Soc.Law No.3, 1982, 259.

83. Ibid.

84. See infra para. 8. 
already mentioned, the idea of socialist ownership is virtually unknown. The need for something like operative management is not heard. The few factories in the country after having been nationalized are directly owned by a State corporation, or as in the case of the new Somalfruit, by a mixed joint-venture, funded mainly by the Italian cooperation program.

Even where, as in land law, the Soviet pattern has been more closely followed, many elements of originality may still be found. First of all, the absence of the typical Eastern European classification of property rights makes itself felt even in respect of land use patterns. In Eastern Europe, legislation determines in which categories land must be classified. Different rules usually follow different classifications in each country. For example, in the Soviet Union land can only be the subject matter of State ownership. In Czechoslovakia it can fall into any category except that of personal ownership; Rumanian law even allows the last mentioned category. ${ }^{85}$ In Somalia, as we have seen, even if in theory the State is the owner of all land, in practice it only exercises a right of eminent domain. Legal rules are not the consequence of a particular statutory classification but the product of the complex interplay of statutory law with different sources among which customary law is by and large the most important. Other aspects of originality are more technical. Among these the opportunity of entrusting land to its user may be mentioned (whatever individual or cooperative it may be), not only on a permanent basis (as in Soviet kolkhozes) but also for a limited term.

\section{Private Law for a Mixed Economy: Suggestions for the Future}

In conclusion, let me first say that the following comments are merely intended to provide a basis for discussion and make no claim whatsoever to being complete. Two assumptions constitute the basis of this discussion: firstly, after the production crisis became evident at the end

85. Compare Knapp, op.cit. note 77, 43. 
of the seventies, the Somali government acknowledged the need for corrective measures and effected a major shift in policy which is still developing today: it (i.e., the government) has slowly moved away from State control and ownership towards a more market oriented economy. ${ }^{86}$ Secondly, the idea that the settlement of the largest possible number of the Somali nomadic population is an important prerequisite for the process of economic and social development of the country has recently been challenged in a very effective way. ${ }^{87}$

It seems to me that both these political and ideological revolutions call for new legal tools to handle them. The aim of this section is to see in which direction we should start our search for them.

From the point of view of the first assumption, we may mention here that the main reason for the unsatisfactory growth performance of the entire economic sector (particularly of agriculture) was due to the fact that "the extension of public sector ownership and control over the economy went well beyond the goverment's resources and managerial capacities". ${ }^{88}$ It has been noted, for example, that while the major part of the national grain production has always been due to small farmers in rain fed areas or flood-irrigation fields, major government policy efforts were dedicated to large-scale state farming. The result of this ideological choice has been that "for almost one decade the backbone of the Somali farming society, the small and medium-scale farmer, has been neglected". ${ }^{89}$ This neglect was at its maximum during the disastrous drought of 1974 and 1975 . The beginning of the timid liberalization process has been marked by two consecutive agreements with the International Monetary Fund in 1983 and by the preparation of a medium term recovery program. All these steps were characterized by policies to encourage private sector initiatives and investment. In the

86. See Conze and Labahn, "From a Socialistic System to a Mixed Economy", in Somalia: Agriculture, op.cit. note 64, 18.

87. See Janzen, op.cit. note 71. See also the proceedings of the "Economy and Development" panel of the IV Congress of Somali Studies field held in Mogadishu, Somalia 25-30/6/1989.

88. Conze and Labahn, op.cit. note 86, 18.

89. M. von Boguslawski, "The Crop Production of Somalia", in Somalia: Agriculture, op.cit. note $64,23-53$. 
domain of agriculture the first signs of progress have already been registered by the experts. ${ }^{90}$

Turning to the second assumption, the initial programs of forced settlement of the nomads, inspired by the Soviet experience in certain peripheral parts of the USSR, had to face two major obstacles: first of all, a serious environmental danger due to the impact of excessive grazing without any periodical rotation, and, secondly, a very serious problem of integration of the former nomads both vis-à-vis settled groups in the countryside and vis-à-vis life in the town. This is not the place, however, to spend much time on a subject in which there is much sociological literature. What may be added here is that

in the North African and Asian dry belts, due to climate, hydrology and lack of suitability of the soil, the nomadic pastoral economy represents the only alternative for an economically efficient use of the natural resources in the large areas. In fact, with the exception of the two particularly favored areas at the Juba and Shabelle rivers, this holds true for the largest part of Somalia. ${ }^{91}$

These brief remarks lead us to the conclusion that from the point of view of economic efficiency and therefore of development, a wise policy would be one of creating sound bases for the free development of smallscale agriculture and nomadic or quasi-nomadic grazing and cattle feeding.

The evolution towards a static (settled) population though attractive from the point of view of the State's control of the population, does not seem to constitute a sensible target in the short run from the point of view of economic development. It would be better to create the conditions for a spontaneous settlement that will certainly happen as soon as valid alternatives are created in the domain of agriculture or urban employment.

90. See the statistics contained in Somalia: Agriculture, op.cit. note 64. Whether there has been real improvement was questioned in discussion at the IV Congress of Somali Studies, op.cit. note 87.

91. Janzen, op.cit. note 71,83 . See the bibliography provided there at $90-91$. 
For the moment, a sound legal and economic policy should take into account that "there exists today a confusing multiplicity of semi-nomadic or similarly structured economic systems and life styles somewhere between the two extremes of complete nomadism and a totally sedentary existence"'.92 From the point of view of legal organization, this calls for a wider role of the individual centered model offered by private law. To achieve development people must be motivated and not forced. This is the challenge for modern African democracy. But the individual centered model must be structured in order to become a mixed organization avoiding the dangers of speculation that it produced during the colonial experience. Such a modified model of property could at the same time provide the legal framework for small-scale agriculture and for the gradual transformation of Somali society to a settled nature. In every historical experience, integration of one large social group into another with different customs and ways of life is a traumatic experience. The need for authoritative and, at the same time, flexible legal rules is in this respect an essential condition. ${ }^{93}$ From the more specific point of view of a developing country, the same need for legal tools, both varied and flexible, comes from the very idea of development. As has been pointed out, development is, in fact, a comprehensive process of change in which economic growth (increase in production), technical modernization, social change and cultural development combine as inseparable and independent parts of a whole. ${ }^{94}$

The first target of the law must be not to impair this process of change. This is why in the domain of the law of property, a larger role of the individual centered model must be welcome. This is not, in principle, incompatible either with an idea of eminent domain of the State or with that of cooperative ownership.

To motivate individual property and entrepreneurship does not mean

92. Janzen, op.cit. note $71,77$.

93. The role played, from this point of view, by the American Courts during the socalled "formative era" of American law in physical conditions not much different from the actual African ones should be always kept in mind. Compare G. Gilmore, The Ages of American Law, New Haven 1979.

94. Compare Th. Bergmann, "Der Beitrag des Agrarsektors zum Entwicklungsprozeß", in Agrarreform in der Dritten Welt, (Elsenhans and Harmut, eds.), 1979, 103. 
to promote selfishness. The reason why the individual centered model introduced during the colonial days ended in failure was due to the fact that absolute property rights were allocated to individuals without binding the holder to the responsibility which should accompany them. As modern legal and economic literature has pointed out, to allocate a property right means giving the holder a power of decentralized decision making. ${ }^{95}$ Power should not be exercised without responsibility as happened in the colonial days when colonizers received a power of using and abusing land without paying back to the community the price that their activity was making the whole community pay. It is not surprising within this logic of exploitation that the Napoleonic model of land use organization has scarcely developed the remedial devices that can guarantee the internalization of social costs. On the contrary, a beneficial individual centered model of property must empathize particularly with the matter of internalization of social costs. Property right holders must not exploit the community but should always pay for the resources they use. Once this initial social obligation is performed, then individual property rights will pursue their real social function: stimulating individual entrepreneurship and in this way increase the productivity of every piece of land.

In order to pursue this task there is a need for rules to handle such problems as pollution, overgrazing in certain areas, water rights, location of activities which create nuisances, funding for urban public health facilities, and so on. These problems can certainly be tackled by means of the traditional public law through centrally enforced regulations on the model of those used in 1810 in France to regulate Les Etablissements Insalubres ou Incommodes and which have also been introduced in some parts of francophone Africa. Or they may be tackled, in an urban context, by means of zoning ordinances, like the racially oriented ones of the colonial period. ${ }^{96}$ But the failure in Africa of such

95. Compare the paper of R. Coase, "The Problem of Social Costs", in Journal of Law and Economics 1, 1960. A comparative discussion on the matter of decentralized decision making and a critical review of "property rights" literature is provided in Mattei, op.cit. note 67.

96. See Tribillon, "Genes et development du droit de l'urbanisme" in Koussagan, op.cit. note $22,297$. 
authoritative models which anybody may see by just walking around any African town should teach something to any intelligent reformer. ${ }^{97}$

There is a private law alternative to all of this: an alternative offering a way of dealing with everyday problems by using the decentralized power of the courts. This is an alternative which respects freedom, gives individuals responsibility and, what is most important in Africa today, does not impair the process of development. This is an alternative which leads to the application of and promotes the development of specifically African legal rules. In the past courts have already demonstrated their efficiency in handling processes of development in many social and geographical situations. ${ }^{98}$ They may provide the rules - authoritative, flexible and suited to the circumstances - that may become in the not so distant future the framework for development.

Obviously not all courts will be fitted to this role which we can define as arbitrating the autochthonous development. They must be equipped with a particular kind of judge, who must be the best product of a specifically African legal culture. These judges must not be bureaucrats nor politicians. They must be technocrats, social engineers, and most of all, scholars on the bench. ${ }^{99}$

This is why there must be a multilateral concerted effort, especially in technical cooperation, to provide the means to develop this kind of legal culture.

But maybe we go too far. What can we suggest to Somalia within the limited scope of this paper? First of all, to return all jurisdiction on mat-

97. Compare Barry and Rieddel, "The Migration to the Cities of West Africa: some Policy Considerations", 16 Journal of Modern African Studies 1978, 241; Ankerl, "Rapid Urbanization in the Third World with Special Reference to Tropical Africa: Social Impact and Perspectives", Labour and Society 1978, 277; Migration and transformation in modern African society, (Binsberger and Meilinnik, eds.), Leiden 1978; Vennettier, Les villes d'Afrique Tropicale, Paris 1976; Coquery and Vidrovitch, Villes et Problemes urbains contemporains en Afrique Noire, recherches en histoire contemporaine, Paris 1984.

98. See op.cit. note 83. As to the proficiency of Courts to frame legal rules suited to the circumstances see Veitch, "Some Examples of Judicial Law Making in African Legal Systems", 34 Modern Law Review 1971, 42.

99. On the necessity of an African legal culture and on its possible role within the process of development see M. Guadagni, in Legal Scholarship, op.cit. note 66. See also P.G. Monateri, "Interpreting Somali Law", paper delivered at the IV Congress of Somali Studies, see note 87. 
ters of property to ordinary courts: being staffed by lawyers they seem to me to be more suitable for handling the difficult alchemy of property rules and liability rules which is the secret of efficient land use. Secondly, to select the best part of every legal model available in order to obtain suitable solutions. Political ideology has not produced the framework for development anywhere, but legal rules created by experience may fill this void. 
